\title{
The Confluence Zone of the Intense Katabatic Winds at Terra Nova Bay, Antarctica, as Derived From Airborne Sastrugi Surveys and Mesoscale Numerical Modeling
}

\author{
DAVID H. BROMWICH \\ Byrd Polar Research Center, Ohio Stase Universiny, Columbus \\ THOMAS R. PARISH \\ Department of Atmospheric Science, Universiny of Wyoming, Laramie \\ CHRISTIAN A. ZORMAN ${ }^{1}$ \\ Byrd Polar Research Center, Ohio State University, Columbus
}

\begin{abstract}
The surface wind field inland of the intense coastal katabatic wind regime at Terra Nova Bay. Antarctica. has been studied both observationally and numerically. Airborne surveys of windinduced features on the snow surface have been used to construct the time-averaged winter surface airflow pattern. The surface motion field has also been simulated by a mesoscale primitive equation model using terrain slopes with a horizontal resolution of $32 \mathrm{~km}$. Both methods of analysis demonstrate that the intense katabatic airstream at Terra Nova Bay is forced by converging air currents in the continental interior. The broadscale confluence zone becomes organized into two regions within about $180 \mathrm{~km}$ of the coast. The primary route for katabatic mass transport into the Terra Nova Bay area is Reeves Glacier valley, but an important secondary source is provided by airflow down David Glacier. The former is generated by the Coriolis-induced concentration of mass transport on the left side (looking downwind) of the broadscale confluence zone as well as by the near-coastal mountain deflection of airflow into the valley head. The confluence zone feeding into David Glacier valley stretches over $100 \mathrm{~km}$ into the interior and is forced by the broadscale terrain configuration of the ice sheet. Source areas for the two airstreams differ with Reeves Glacier valley being fed by cold air formed well into the interior, whereas the airflow down David Glacier is sustained by radiative cooling over lower parts of the ice sheet which are much closer to the Ross Sea. Evaluation of the observational and modeling results reveals both the strengths and weaknesses of each approach. Airborne surveys of sastrugi orientations are a highly successful method for establishing the detailed pattern of surface airflow. However, a systematic examination of sastrugi dimensions suggests that such work could also be carried out using SPOT-type satellite observations, which is a more cost-effective approach than aircraft surveying. The double-jet structure of katabatic airflow into the Terra Nova Bay area is well represented by the primitive equation modeling, but much finer grids are needed to resolve the near-coastal drainage details.
\end{abstract}

\section{INTRODUCTION}

The continental-scale surface wind field over Antarctica is a key climatic component in the southern hemisphere whose effects are manifested well into the middle latitudes [James, 1988] and throughout a substantial depth of the atmosphere overlying the continent [Polar Research Board, 1984, p.10]. Yet description and study of this phenomenon have been severely limited by the continent's remote location and harsh climate. Two recent developments are drastically altering this situation. Automatic weather stations (AWS) which transmit observations to NOAA polarorbiting meteorological satellites can be deployed in remote areas and have a high probability of operating successfully throughout the year. The fraction of ice sheet areas moni-

\footnotetext{
${ }^{1}$ Now at Department of Physics, Case Western Reserve University, Cleveland, Ohio.
}

Copyright 1990 by the American Geophysical Union.

Paper number 89JD03027. 0148-0227/90/89JD-03027\$05.00 tored by these units continues to expand, with the result that surface climatic processes are being diagnosed more completely [Siearns and Wendler, 1988].

The second development is that the ice sheet topography has been determined with unprecedented precision [ $D$ rewry, 1983]; elevations are known with an uncertainty of about 30 $m$ for the entire continent. Based upon a realization that the prime forcing of Antarctic drainage winds is gravity acting on radiatively-cooled air over sloping terrain [Parish, 1982], Parish and Bromwich [1987] have diagnosed the pattern of surface airflow over Antarctica from the simple steady state model of Ball [1960]. Input data consisted of terrain slopes at $50-\mathrm{km}$ resolution and estimates of the boundary layer stratification [Phillpor and Zillman, 1970]. Surface air does not blow radially and uniformly away from the highest parts of the ice sheet, but rather is highly irregular with regions of pronounced confluence and difluence. Where negatively buoyant air from a large interior section of the ice sheet converges, the supply of cold air to sustain katabatic winds blowing down the marginal ice slopes is considerably enhanced [Parish, 1984]. Such confluence regions in the interior wind field are believed to be the prime cause of the intense katabatic winds monitored at Cape Denison and Port Martin in Adelie Land [Parish, 1981]. The resulting highly irregular transport of katabatic air across the Antarctic coastline is of 
supreme importance in determining the effects of the ice sheet boundary layer circulation upon the atmosphere and the ocean surrounding the continent.

Terra Nova Bay is located downwind of a pronounced confluence region in the simulated interior wind field of Parish and Bromwich [1987]. Consistent with the arguments outlined above, the coastal katabatic winds are known from the historical records of Scott's Northern Party. who were forced to winter in this area during 1912, to rival those of Cape Denison and Port Martin in terms of persistence and strength [Bromwich and Kurtz, 1982, 1984]. Recent AWS observations have shown that the surface wind speed averages $17 \mathrm{~m} \mathrm{~s}^{-1}$ for the fall months of February to April with speeds mostly varying between 10 and $30 \mathrm{~m} \mathrm{~s}^{-1}$ [Bromwich. 1989]. A joint study, directed by the first two co-authors, is being conducted to describe the kinematics and dynamics of this intense katabatic airstream. The investigation is directed toward obtaining an enhanced understanding of coastal katabatic wind regimes which are forced by interior confluence zones; these features seem to dominate the boundary layer circulation over the ice sheets of Antarctica.

This paper combines observational analysis and numerical modeling to explore the interior confluence zone which sustains the intense katabatic winds at Terra Nova Bay; a preliminary version of this work was presented by Broniwich ef al. [1988]. The snow surface over the plateau to the west of Terra Nova Bay has been extensively photographed from the air. Section 2 describes these surveys of windforced features at the snow-air interface which allow the time-averaged streamlines of surface air motion to be established with unprecedented spatial resolution. The interior wind field has also been simulated by the three-dimensional version of the mesoscale numerical model of Parish and Waight [1987]. and the results are presented in section 3 . The last section compares and contrasts the observational and modeling studies of the confluence zone, and concludes that the discrepancies are primarily due to the grid spacing used in the model calculation.

\section{SASTRUGI-DERIVED STREAMLINE FIELDS}

\subsection{Flight Surveys}

Sastrugi are wind-formed minor relief features at the snow surface whose orientations mirror the direction of the wind that generated them. The literature contains two definitions of what entities constitute sastrugi. Roscoc [1953] and Alley [1989] define all aeolian-forced features to be sastrugi, but Mather [1962]. Doumani [1967], Fujiwara and Endo [1971], and Watanabe [1978] discriminate between depositional (snow dunes ( $=$ whalebacks) and barchanoids) and erosional (called sastrugi) forms. The varying definition appears to arise in part because of areal variations in typical depositional conditions. Around Siple Coast, for example, most snow seems to be deposited in conjunction with light winds or downslope storm winds (M. Strobel, personal communication, 1989). These can then be eroded by downslope drainage winds so that depositional and erosional forms are parallel to the prevailing wind direction. By contrast inland of Syowa Station, precipitation is usually accompanied by strong cross-slope cyclonic winds and snow dunes form by forced deposition [Walanabe, 1978]; subsequently these are carved by drainage winds. The typical angular deviation between depositional and erosional forms on Mizuho Plateau is $50^{\circ}$ [Fujiwara and Endo. 1971]. Automatic weather station observations from inland of Terra Nova Bay (discussed in section 2.3) show that almost all winds come from a narrow angular range. Depositional conditions inland of Terra Nova Bay thus appear to be similar to those at Siple Coast. Because the predominant linear depositional and erosional forms may not be readily distinguishable from the air, the sastrugi definition of Roscoe [1953] and Alley [1989] is adopted here.

Sastrugi form rapidly in hours to days [Mather, 1962; I.M. Whillans, personal communication. 1989]. and once age-hardened (sintered) can persist for months [Watanabe, 1978; Okuhira and Narita. 1978, Figure 5]. Because mosi East Antarctic precipitation (approximates deposition) falls during winter [Bromwich. 1988] a sastrugi survey conducted at the end of winter should record sastrugi orientations that formed as a result of many past depositional events. As is demonstrated in section 2.3, analyses of such observations allow the time-averaged airflow pattern to be constructed, a technique pioneered by Mather and Miller [1967]. Some variability of sastrugi directions will inevitably be present in such data sets as a result of atypical but infrequent synoptic forcing [Mather. 1962].

To construct the time-averaged winter surface airflow pattern over the ice slopes west of Terra Nova Bay, airborne photographic surveys of sastrugi orientations were undertaken on November 6, 1986, and November 8. 1987. Early November was chosen as the desirable time period because lighting conditions are favorable for aerial photography, but winter wind conditions still prevail. Both missions were planned and coordinated by Jerry Mullins of the U.S. Geological Survey (USGS) and flown by U.S. Navy personnel using an LC-I 30 transport aircraft. For both missions the LC-1 30 was equipped with a Wild RC-8 camera with a $152.3 \mathrm{~mm}$ focal length. The camera was set at a shutter speed of $1 / 300$ sec., an $f /$ stop of 88 and was loaded with Kodak Panatomic-X aerographic film 2412. The film was developed and processed into a series of $9 \times 9$ in. black and white contact prints which formed the data base for the sastrugi analyses. Photographs were taken with $60 \%$ along-track overlap between successive photographs. Thus inspection of every other print provided complete examination of the photographed region.

The objective of the missions was not to provide complete spatial coverage of the Terra Nova Bay confluence zone, but rather to sample the region in order to capture the overall pattern of the surface airflow. Hence the missions were flown in discrete, well-separated flight legs. The sampling area differed between 1986 and 1987 but there was sufficien overlap to evaluate the interannual variability of snow surface fealures.

The 1986 mission was designed to capture the drainage of David. Reeves and Priestley glaciers. Figure I shows the 1986 flight domain. It consisted of six north-south flight lines approximately $18 \mathrm{~km}$ apart and three cast-west tie lines. The tie lines were to aid in the positioning of the north-south flight lines and to fill in details lying between the north-south lines. The mission was flown between 1858 UTC on November 5 and 0314 UTC on November 6 in 1986. The aircraft ground speed ranged from 435 to $514 \mathrm{~km}$ $h^{-1}$ with an average of $480 \mathrm{~km} \mathrm{~h}^{-1}$. The aircraft flew at a constant height of $5390 \mathrm{~m}$ above sea level. Because the terrain elevation ranged from 200 to $2200 \mathrm{~m}$. the aircraft altitude varied from 3190 to $5190 \mathrm{~m}$. Since the scale of each photograph depends upon the aircraft height above the photographed region. the scale changed throughout the region from $1: 20,950$ at $3190-\mathrm{m}$ altitude to $1: 34,080$ at $5190-\mathrm{m}$ altitude. Consequently, at $3190 \mathrm{~m}$ abqve the terrain the sampled area per photograph was $22.9 \mathrm{~km}$, while at $5190 \mathrm{~m}$ it was $60.7 \mathrm{~km}^{2}$. The smallest resolution, found by calculating the resolution of the photograph with the smallest scale, was $5 \mathrm{~m}$. Positional uncertainty was calculated to be a maximum of $\pm 2 \mathrm{~km}$, and was greatest in the northwest section of the flight domain due to the lack of locally prominent terrain features with which to tie the flightlines. This positional uncertainty is no problem, however, because changes in sastrugi directions in this region are largescale, occurring over tens of kilometers. The total number of photographs in the 1986 mission was 945.

The 1987 mission was designed to resolve the broadscale structure of the Terra Nova Bay confluence zone, and is also shown in Figure 1. Because the 1987 and 1986 flight legs overlapped around David and Reeves glaciers, interannual variability can be investigated. The 1987 flight domain consisted of five flight legs, four comprising the sides of 


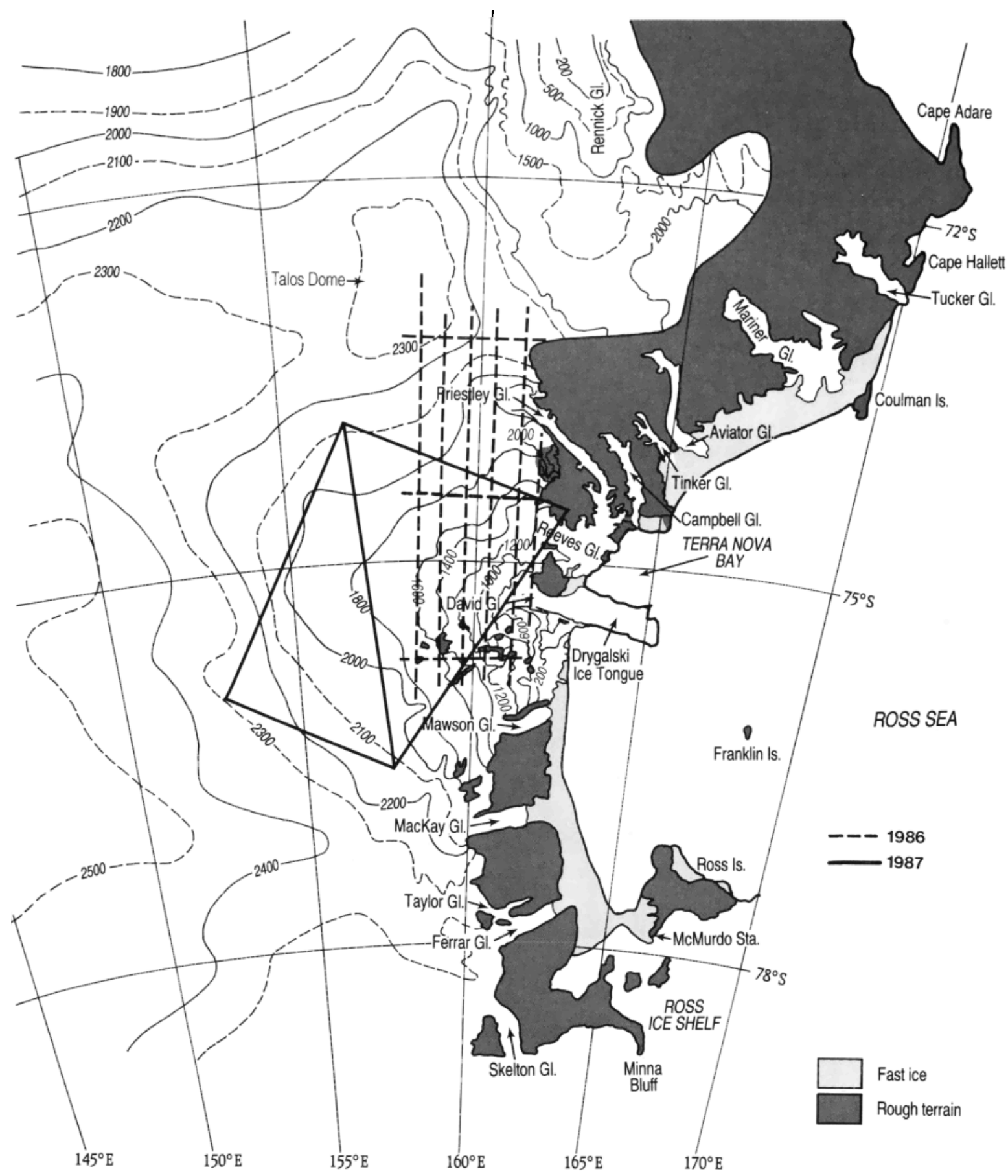

Fig. 1. Regional location map. Ice sheet elevation contours in meters (solid and dashed) were obtained by merging Drewry's [1983] interior analysis with USGS 1:250,000 reconnaissance maps for the coastal regions. The 1986 and 1987 sastrugi survey flight legs are shown by the heavy dashed and heavy solid lines, respectively.

a box, the fifth being a tie line connecting the northwest
and southeast corners. The mission was flown between 1600 and 2200 UTC on November 8, 1987. The aircraft flew at an average ground speed of $432 \mathrm{~km} \mathrm{~h}^{-\mathrm{r}}$ at a height of $5390 \mathrm{~m}$ above sea level. The terrain elevation ranged from 400 to $2250 \mathrm{~m}$; therefore, the aircraft altitude ranged from 3140 to $4990 \mathrm{~m}$, the photographic scale from $1: 20,620$ to $1: 32,760$, and the sampled area per photograph from 22.2 to $56.1 \mathrm{~km}^{2}$. As in the 1986 mission, the resolution per photograph was 5 $m$ and larger. The maximum positional uncertainty was $\pm 4 \mathrm{~km}$, and the number of photographs was 575 .

\subsection{Data Collection and Analysis}

2.2.1. Layout of flight lines. Upon receipt of the photographs from the USGS, the photographs for both the 1986 and 1987 missions were laid out in their flight leg configurations and checked for prominent terrain features such as mountains, glacier valleys and nunataks, as shown on the USGS $1: 250,000$ reconnaissance map series. Using these terrain features as reference points and the mission plans as guides, the flight and tie lines were plotted on the detailed USGS maps. The flight domain for the 1986 mission 
was characterized by prominent terrain features only in the southern and eastern portions. Thus the confidence in the position of the north-south flight lines decreased in the northern and western portions of the domain. By beginning with the easternmost flight line and working west, the tie lines not only positioned the north-south flight lines in relation to the terrain, but also in relation to the other north-south lines. This method worked well in all but the northern section of the westernmost flightline where the exact intersection of the tie line with the flight line could not be found. However, it was possible to determine a $4 \mathrm{~km}$ square containing the intersection by looking for slight changes in sastrugi size and orientation.

Unlike the 1986 mission, the flight domain for the 1987 mission was characterized by identifiable terrain features only in the northeast section. Thus only two flight lines could be accurately positioned using terrain features. The position of the other flight lines and the diagonal tie line were fixed by searching for changes in sastrugi size and orientation. While the exact intersection points could not be found, $8 \mathrm{~km}$ squares containing the intersections were located.

2.2.2. Extraction of directional information. Sastrugi were readily identifiable throughout both flight domains. Sample air photographs are not presented here because the prints do not contain sufficient contrast for sastrugi to be clearly resolved in gray-shade reproductions. Roscoe [1953, pp. 76-77] and Wendler [1988] give examples of photographs of sastrugi taken from much lower altitudes. Most sastrugi (Figure 2) were of the linear type [Roscoe, 1953, p. 76] but barchanoids [Doumani. 1967] predominated to the north of the Reeves Glacier entrance. Resolvable linear sastrugi generally ranged in size from 10 to $181 \mathrm{~m}$. In parts of the 1986 flight domain, some very large linear features were present which had an average length of $600 \mathrm{~m}$ and a maximum length of about $1 \mathrm{~km}$. These features seem to disappear when the photographs are examined with a magnifying glass, and often have regular-sized sastrugi on top of them. Previous aerial surveys have reported much longer sastrugi than seen from the ground: up to $240 \mathrm{~m}$ [Roscoe, [953, p. 78] compared with typical surface estimates of a few meters [e.g. Roscoe, 1953; Doumani, 1967]. It is likely that the spatial organization of these relatively low-amplitude features is obscured by oblique observation from the surface [compare Roscoe, 1953, p. 78]. It seems from the comments of Mather [1962, p. 167] that many of the sastrugi seen on the air photographs are depositional in origin. Airborne photographic surveys offer the distinct advantage of spatial integration, and provide data which can be reanalyzed. The primary spatial organization in Figure 2 is the increase in length of linear sastrugi with elevation. This must result from the interaction between the atmospheric and ice surface characteristics that govern sastrugi evolution [e.g.,
[e. Roscoe, 1953, p. 76], but is not a simple function of the surface wind field dynamics.

Sastrugi orientations were easily discernable in most areas, and the following strategy was employed for both missions to extract these data. Each independent photograph was divided into quadrants and the direction of the primary sastrugi (called the primary direction) was found for each quadrant. Primary sastrugi were those whose spatial frequency (number per unit area) was generally twice as high as those of sastrugi with different orientations. If the angular range of quadrant directions was less than $20^{\circ}$, then all quadrant directions were averaged, yielding a single primary direction for the photograph. If the angular range exceeded $20^{\circ}$, then the quadrant directions were organized into groups where the angular range was less than $20^{\circ}$. Then the members of each group were averaged, yielding multiple primary directions for the photograph. Primary sastrugi directions were assigned to the centerpoint of the respective photographs.

(i) Linear Sastrugi $(1,2,3$ or 4$)$

a

\begin{tabular}{ccc} 
& \multicolumn{2}{c}{ Wind direction } \\
Type & Average Length & Range of Lengths \\
\hline 1 & $13 \mathrm{~m}$ & $10 \mathrm{~m}$ to $16 \mathrm{~m}$ \\
2 & $43 \mathrm{~m}$ & $21 \mathrm{~m}$ to $73 \mathrm{~m}$ \\
3 & $51 \mathrm{~m}$ & $21 \mathrm{~m}$ to $73 \mathrm{~m}$ \\
4 & $114 \mathrm{~m}$ & $80 \mathrm{~m}$ to $181 \mathrm{~m}$
\end{tabular}

Note- Type 2 linear sastrugi is a well-defined, singular unit while type 3 occurs in densely-packed bunches.

(ii) Barchanoid Sastrugi (B)

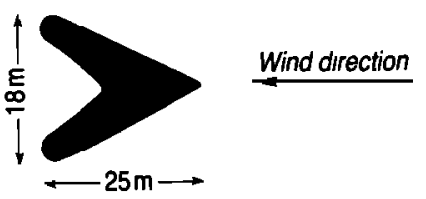

(iii) Ripples (R)

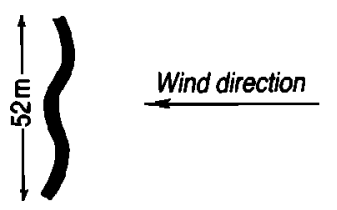

(iv) Drift Plumes (DP)

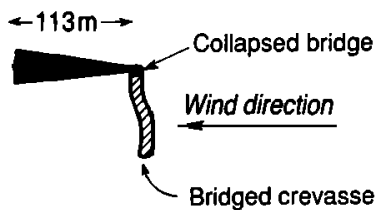

Fig. 2. Primary wind-generated snow surface features within the confluence zone. (a) Classification scheme. (b) Spatial organization data for every tenth photograph are plotted for both 1986 and 1987 flight legs.

In many photographs, less prominent sastrugi with markedly different orientations to those of the primary sastrugi were also present. In no instance was the distinction between these two groups in doubt; this is another consequence of the spatial averaging provided by airborne photographic surveys. It is probable that a surface-based observer with his limited field of view is more likely to confuse primary and secondary sastrugi. The latter are probably generated by short-term, synoptically forced modifications of the time-averaged airflow. Primary sastrugi directions are presumed to follow the gravity-driven winter drainage of surface air, and the generally disorganized secondary directions were omitted from the present analysis.

In order to successfully represent the surface wind field within the confluence zone, the primary sastrugi directions from the 1986 and 1987 missions had to be merged. But in order to justify such a combination, it was necessary that the interannual variability of primary sastrugi directions for regions common to both missions be insignificant. Because the overlap of flight domains provided many such 


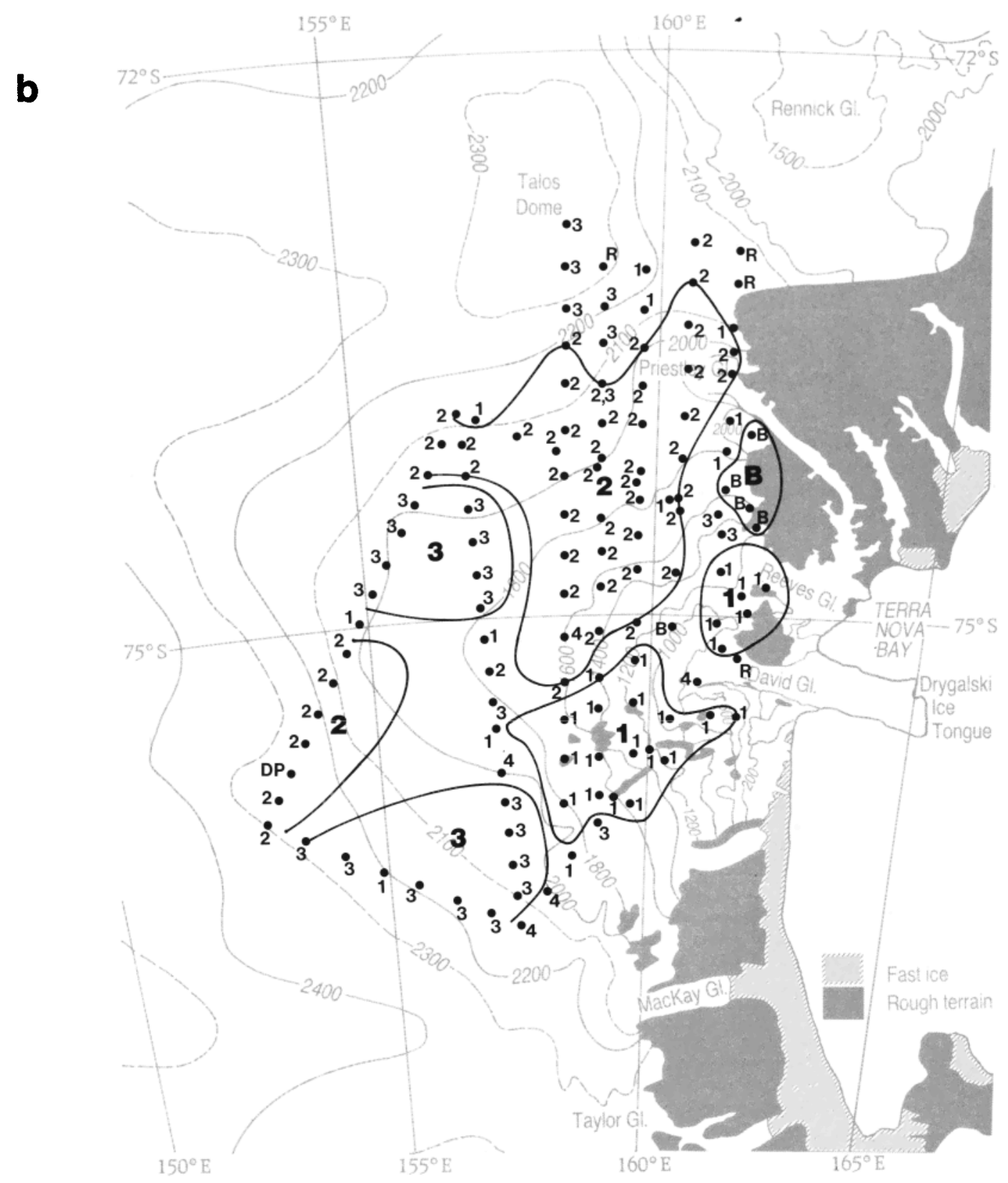

Fig. 2. (continued)

regions, the variability of primary sastrugi directions was examined and the results tabulated in Table 1 . The comparison indicated a mean absolute difference of $6.2^{\circ}$ with a maximum difference of $\pm 12^{\circ}$. Because the mean absolute difference is small compared with the criterion used to determine a primary sastrugi direction, differences between the two years were insignificant. Hence the methods used in obtaining the streanline pattern are justified, and it will be assumed that the streamline pattern represents the surface wind field conditions for late wintertime regardless of the year.

\subsection{Sireamline Analysis}

Manual streamline analysis was performed on the field of primary sastrugi orientations. Streamlines were started at equidistant intervals around the western and southern edges of the photographed area and followed to the eastern boun- dary. The resulting pattern is well established, being only slightly influenced by the multiple sastrugi directions encountered in the transition areas between drainage regions for particular glaciers.

Figure 3 shows the resulting time-averaged airflow pattern. The domain is basically divided into two parts with winds to the north of $74^{\circ} 40^{\prime} S$ converging into Reeves Glacier valley and those to the south draining down David Glacier. The steep mountains to the southwest of Priestley Glacier (with peaks to $2800 \mathrm{~m}$ ) block the approaching stable airstream and deflect it to the right down the trough leading to Reeves Glacier. This barrier effect for drainage winds, which was inferred by Bromwich and Kurtz [1984] from the theoretical study of Ball [1956], plays a key role in setting up the airflow down Reeves Glacier. Figure $4 a$ provides a more detailed look at this barrier jet. If the flight line oriented in the direction of WNW from Skinner Ridge is 
TABLE 1. Variability of Primary Sastrugi Directions Inland of Terra Nova Bay Between 1986 and 1987

\begin{tabular}{|c|c|c|c|c|c|}
\hline \multicolumn{2}{|c|}{$\begin{array}{l}\text { Location of Centerpoint } \\
\text { of Photograph }\end{array}$} & \multirow{2}{*}{$\frac{\text { Average Sastrugi }}{1986}$} & Direction, deg & Difference, deg & \multirow[b]{2}{*}{ Remarks } \\
\hline Latitude, deg S & Longitude, deg E & & 1987 & $(1986-1987)$ & \\
\hline $74^{\circ} 30.77^{\prime}$ & $161^{\circ} 37.94^{\prime}$ & 337 & 339 & -2 & \\
\hline $74^{\circ} 29.81^{\prime}$ & $161^{\circ} 10.81^{\prime}$ & 341 & 341 & 0 & \\
\hline $74^{\circ} 22.50^{\prime}$ & $160^{\circ} 23.71^{\prime}$ & 276 & 283 & -7 & \\
\hline $74^{\circ} 18.02^{\prime}$ & $159^{\circ} 48.00^{\prime}$ & 302 & 290 & +12 & \\
\hline $74^{\circ} 13.29^{\prime}$ & $158^{\circ} 23.57^{\prime}$ & $\left.\begin{array}{l}296 \\
320\end{array}\right\}$ & $\left.\begin{array}{l}292 \\
325\end{array}\right\}$ & $\begin{array}{r}+4 \\
-5\end{array}$ & \} transition zone \\
\hline $74^{\circ} 6.59^{\prime}$ & $159^{\circ} 12.58^{\prime}$ & 304 & 314 & -10 & \\
\hline $75^{\circ} 49.98^{\prime}$ & $159^{\circ} 48.00^{\prime}$ & 183 & 195 & -12 & complex topography \\
\hline $75^{\circ} 35.69^{\prime}$ & $160^{\circ} 23.71^{\prime}$ & 224 & 213 & +11 & complex topography \\
\hline $75^{\circ} 14.80^{\prime}$ & $161^{\circ} 9.82^{\prime}$ & 283 & 282 & +1 & complex topography \\
\hline $75^{\circ} 2.83^{\prime}$ & $161^{\circ} 37.94^{\prime}$ & 293 & 297 & -4 & complex topography \\
\hline \multicolumn{2}{|c|}{$\begin{array}{l}\text { Mean difference } \\
\text { Standard deviation } \\
\text { Mean absolute difference }\end{array}$} & & & $\begin{array}{r}-1.1 \\
7.8 \\
6.2\end{array}$ & \\
\hline
\end{tabular}

taken to be representative. the jet is about $30 \mathrm{~km}$ wide, and the shift from airflow toward the mountains to mountain-deflected airflow takes place abruptly in about $5 \mathrm{~km}$.

Surface wind observations from four AWS between February and June in 1988 are available to check the winter streamline analysis (Figure 4a). The directions of the vector-average winds for all observations and for those speeds which exceed the lowest threshold for drifting snow $\left(8 \mathrm{~m} \mathrm{~s}^{-1}\right.$ [Bryazgin. 1986. Figure 1]) agree to within $2^{\circ}$. This arises because, with rare exceptions, the winds blow from one direction. Resultant directions at stations 09 , 23 , and 27 lie along the streamlines. The apparent discrepancy between the direction at station 21 and the streamlines probably arises because 21 is located very close to the edge of the barrier jet where there is a sharp directional gradient. It can be concluded that the sastrugi analysis accurately reproduces the winter surface-airflow pattern.

The broadscale airflow into David Glacier valley is well defined with most cold air coming from plateau areas adjacent to the coast (Figure 3). By contrast. the cold air which blows down Reeves Glacier comes from much farther inland. The prominent streamline confluence zone inland of David Glacier is associated with a trough shown by the 1800 and 2000-m elevation contours. A more accurate topographic survey may reveal that the valley is even more well-defined than appears at present. The shift from southerly airflow toward, to westerly airflow within, the confluence zone (Figure 4b) takes place abruptly along the 1987 tie line within about $4 \mathrm{~km}$. Figure $4 b$ suggesis that the southern edge of the confluence zone can migrate about $25 \mathrm{~km}$ to the north and south of its time-averaged location. The area to the south and southwest of David Glacier (Figure 3) has numerous nunataks. This complicated topography disrupts the surface drainage into the southern half of David Glacier valley.

The 1986 flight lines captured the airflow into Priestley Glacier valley and the southern fringes of the drainage region for Rennick Glacier (Figure 3). The col between these two drainage areas is located by the sastrugi analysis just to the north of the head of Priestley Glacier. The source region for air flowing down Priestley Glacier covers the southern part of Talos Dome and some plateau areas farther west. Airflow into Rennick Glacier valley is discussed in the next section.

\section{MODELING OF THE TERRA NOVA BAY KATABATIC WIND REGIME}

In addition to the observational evidence for the confluence zone paradigm offered by the sastrugi analysis, numerical simulations were conducted in order to provide physical insight into the mesoscale confluence feature and attendant katabatic winds near Terra Nova Bay. The numerical model used is the three-dimensional version of the prinitive equation model discussed in the katabatic wind study of Parish and Waigh [1987] and is a modified version of the model described by Anthes and Warner [1978]. The model is written in terrain-following sigma coordinates and includes 10 vertical levels. The first sigma level corresponds to a height of approximately $20 \mathrm{~m}$ above ground level: the remaining vertical levels are distributed such that the highest resolution is found in the lower portion of the atmosphere. This enables the boundary layer to be explicity resolved. Fluxes of momentum and heat within the boundary layer are modeled using a first-order closure scheme as described by Parish [1984] and Parish and Waight [1987]. A horizontal grid consisting of 25 grid points in the $x$ direction and 21 points in the $y$ direction were used for the simulation. Open boundary conditions as described by Anthes and Warner [1978] are employed in which all prognostic variables are extrapolated outward to the boundaries. Prognostic equations in the model include the two horizontal motion components, temperature, the surface energy budget of Blackadar [1978] and pressure. Explicit representation of the longwave radiative processes is incorporated in the model following Cerni and Parish [1984] to provide a realistic numerical treatment of the cooling processes in the lower atmosphere. This allows the katabatic wind to evolve in a physically consistent manner without the need for ad hoc assumptions regarding the cooling rate.

The ice topography for the Terra Nova Bay region was digitized to a $32-\mathbf{k m}$ grid scale from the contour map of Drewry [1983]. This grid representation resolves the large scale confluence zone structure in the interior of the continent and is sufficient to depict the broadscale structure of the katabatic flow, but individual glacier outlets and irregular mountainous topography are not explicitly represented. The terrain in the vicinity of Terra Nova Bay is extremely complex because of the proximity of the Transantarctic Mountains and numerous mountain peaks adjacent to 


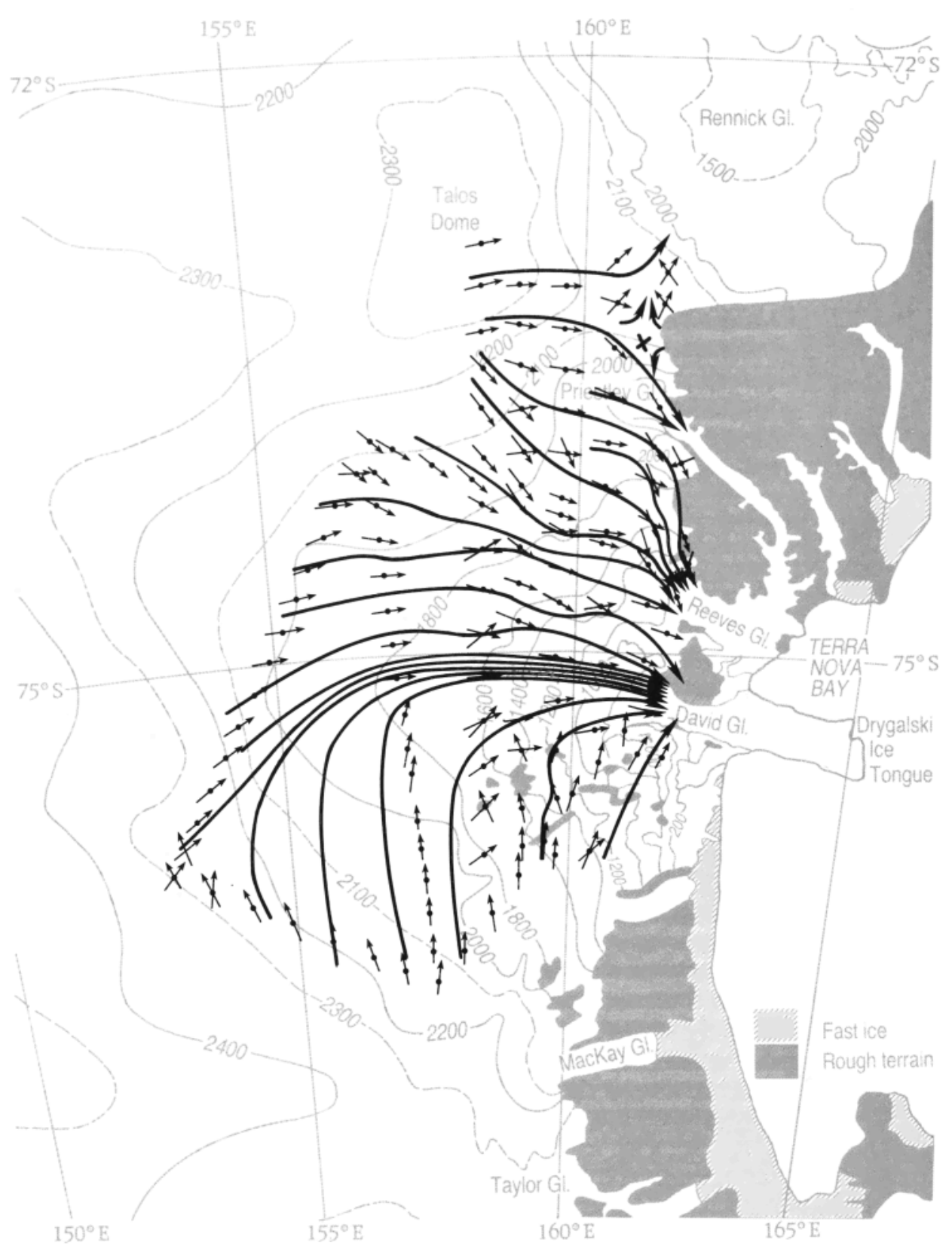

Fig. 3. Time-averaged winter streamlines of surface airflow over the plateau to the west of Terra Nova Bay (heavy continuous lines) as analyzed from the airborne sastrugi surveys. Directions of the primary sastrugi (arrows) are plotted at the centerpoint of every tenth photograph from 1986 and 1987.

Terra Nova Bay. The results therefore, while representative of the mesoscale katabatic wind structure upslope of individual glaciers such as Reeves Glacier, cannot be expected to provide fine-scale information over the very complex terrain to the north and southwest as well as within narrow glaciers such as Priestley Glacier. The model has been initalized about a state of rest to isolate the terraininduced drainage flows without complications introduced by the large scale synoptic forcing. The initial temperature profile used in the initialization process was adapted from the sounding presented by Schwerdffeger [1984, Figure 6.9] and extrapolated to the sea level and is consistent with the initial state of rest in the wind field. Model equations have been integrated for a 12-hour period by which time the katabatic winds are well developed and have reached a near steady state.
The strong radiative flux divergence rapidly cools the ice surface and development of the katabatic wind is abrupt. Within four hours from the start of the model integration, significant drainage flows appear along Reeves Glacier. The result has been observed in other simulations [Parish, 1984; Parish and Waight, 1987] and is supported by data from AWS; the onset of strong katabatic winds at Inexpressible Island adjacent to Terra Nova Bay often occurs with suddenness. Results from the numerical simulations suggest that most of the adjustment of the katabatic winds is complete by eight hours and relatively minor changes take place during the final few hours of model integration. Figure 5 illustrates the streamlines of cold air drainage after the 12-hour simulation for the first and second sigma levels corresponding to heights of 20 and $60 \mathrm{~m}$ above the ice surface. The terrain-induced forcing of the airflow is pronounced; the 
a
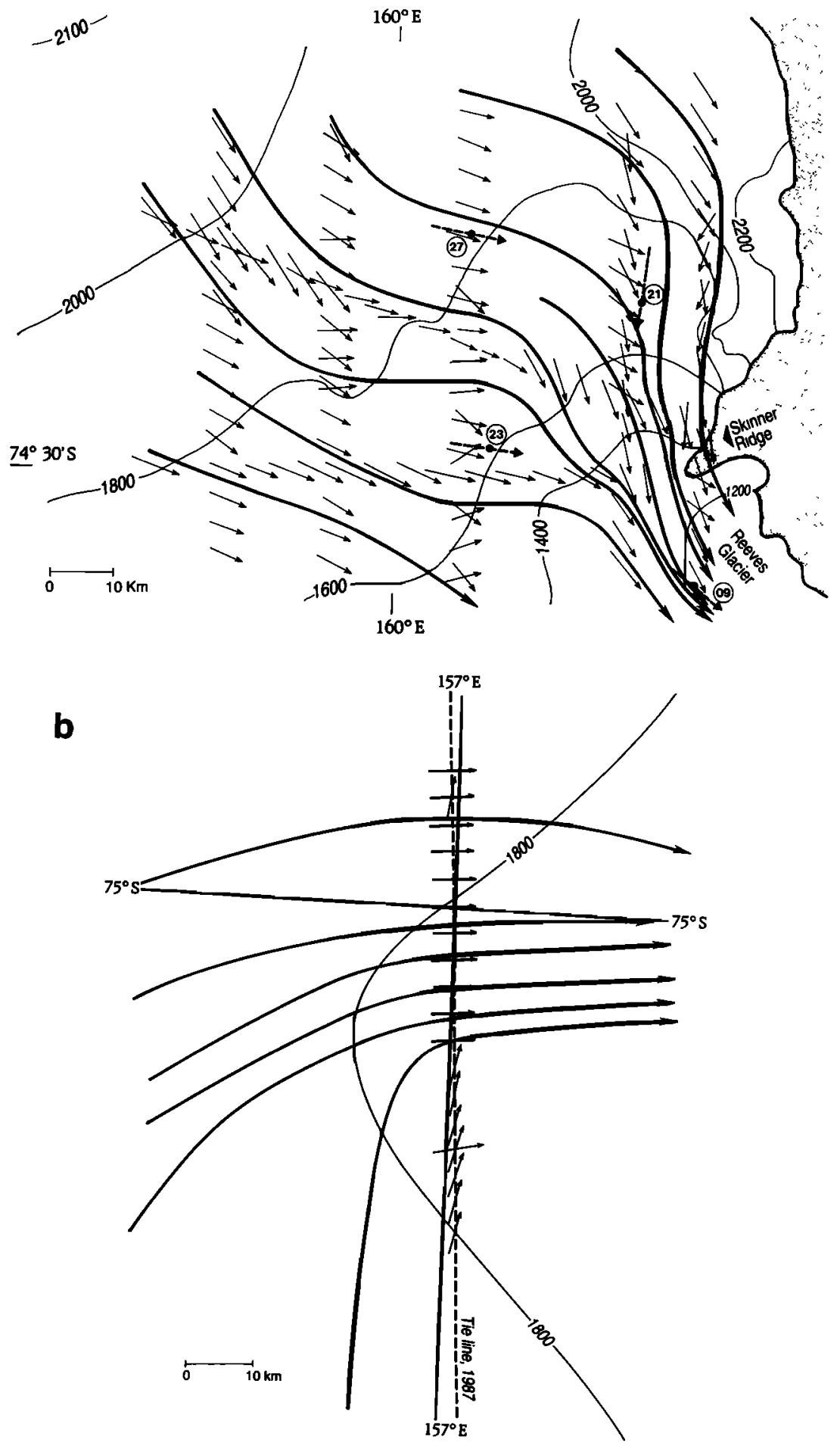

Fig. 4. Detailed descriptions of some prominent features of the inferred winter streamlines. Primary sastrugi directions are plotted at the centerpoint of every second photograph. Complex terrain is stippled. (a) Barrier jet feeding into the northern half of Reeves Glacier valley. (b) Confluence zone upwind of David Glacier. In Fig. 4a, vectoraverage surface-wind directions from AWS sites $09,21,23$, and 27 for February-June 1988 are plotted as heavy dashed lines. Dots mark the AWS locations.

katabatic wind pattern at both levels is strongly influenced by the orientation of the topography in the continental interior. Owing to the larger friction term in the lower part of the atmosphere, the streamlines for the first sigma level are directed some $20^{\circ}$ more downslope than corresponding streamlines for the second sigma level. A clear tendency in the downslope orientation of streamlines is also seen from the gently sloping interior to the steeper ice slopes near the coast. Streamlines are directed at only slight angles to the ice contours in the continental hinterland, becoming directed in a more downslope direction near the steep coastal ice slopes in response to the sudden enhancement in the katabatic acceleration. Two distinct confluence zones are delineated in each streamline depiction upslope from 
a) STREAMLINES $\sigma$ LEVEL $=1$

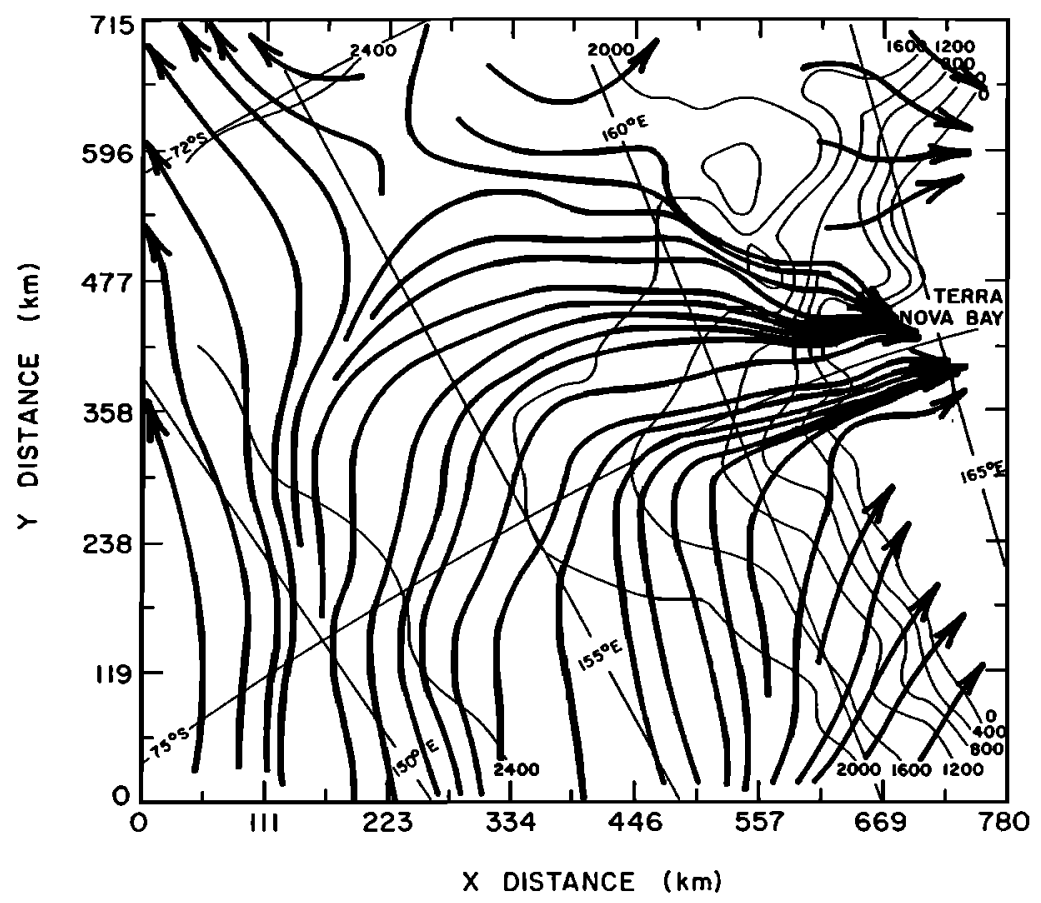

b) STREAMLINES

$\sigma \quad$ LEVEL $=2$

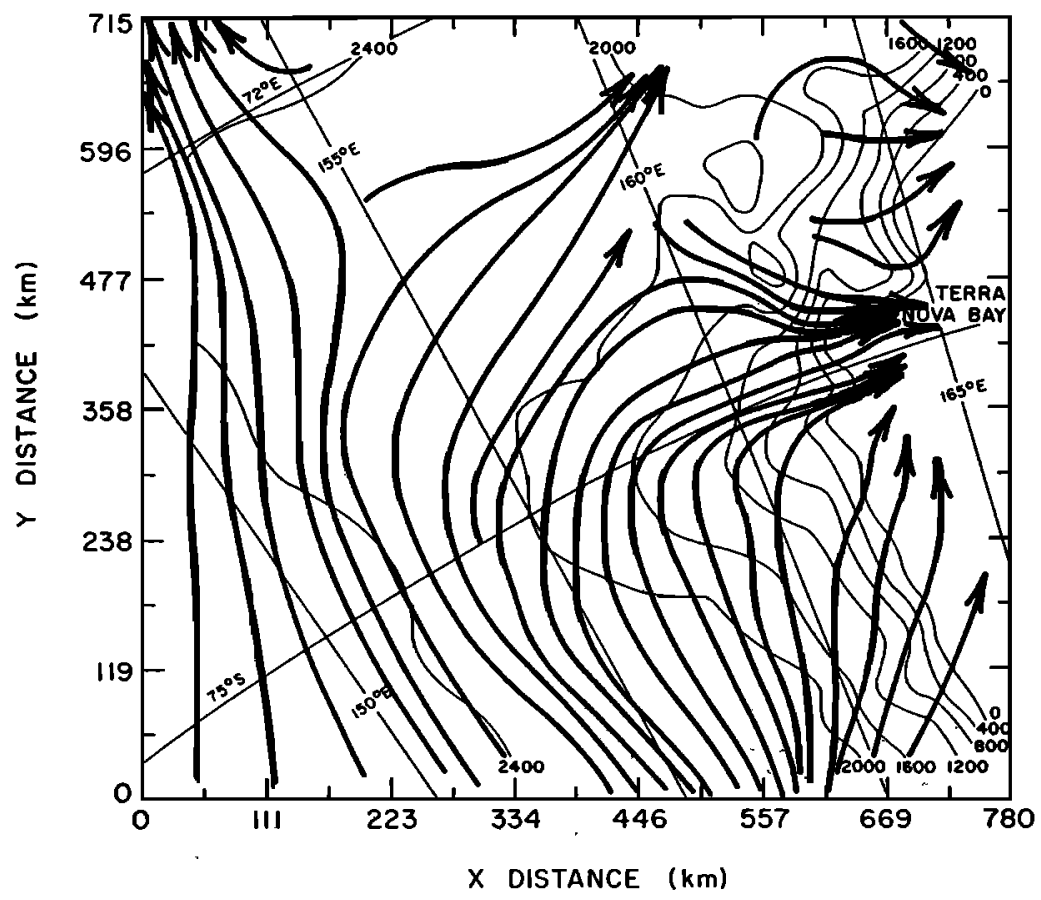

Fig. 5. Model streamlines after 12-hour time integration for (a) first sigma level ( $20 \mathrm{~m}$ above the ice surface) and (b) second sigma level ( $60 \mathrm{~m}$ above the ice surface).

Reeves and David glaciers. The analyses suggest that cold air produced over a broad area in the Antarctic interior drains through only two glacier valleys. The large source area and relative narrowness of the outflow region suggests that a nearly unlimited cold air supply is present upslope of the glaciers and katabatic wind enhancement is to be expected.
Two additional confluence features can be identified to the northwest of Terra Nova Bay on the second sigma level in Figure $5 b$. The confluence zone at the top left corner represents the flow convergence which feeds the Adelie Land coast. This zone is clearly identified in the large scale streamline simulation of Parish and Bromwich [1987]. The second additional confluence feature is situated some $300 \mathrm{~km}$ 

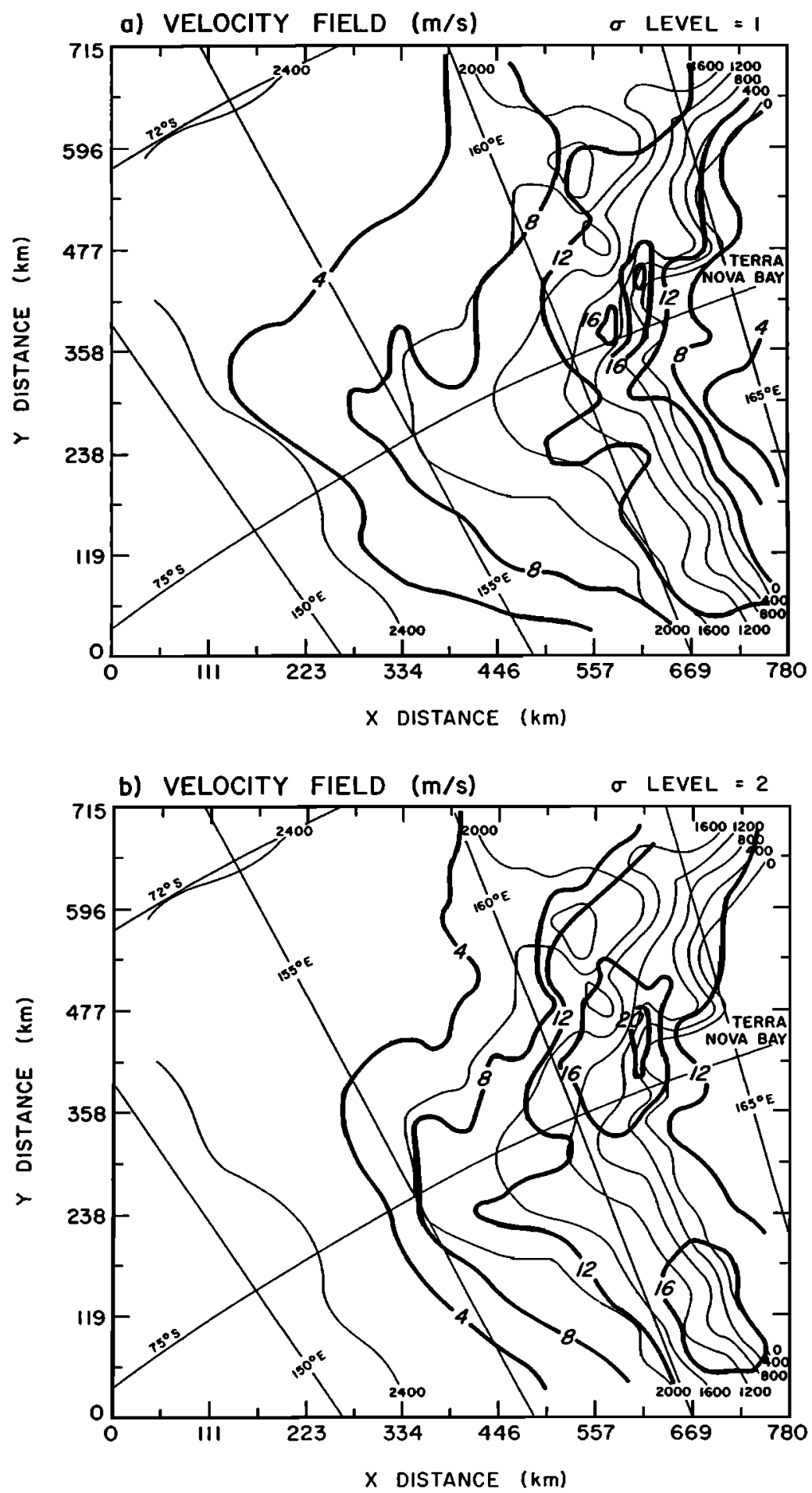

Fig. 6. Model katabatic wind speeds $(\mathrm{m} / \mathrm{s})$ after 12-hour time integration for (a) first and $(b)$ second sigma levels.

northwest of Terra Nova Bay and probably represents cold air drainage into Rennick Glacier valley. A polynya is frequently present just offshore from the foot of Rennick Glacier [compare Kurlz and Bromwich, 1983, Figure 2c; Kurlz and Bromwich, 1985. Figure 4d], and may be generated by offshore katabatic winds when the katabatic airstream fed by the elevated interior confluence zone is forced down to sea level.

The corresponding wind speeds at the first and second levels in the model after the 12-hour simulation are shown in Figure 6. In general, the strongest katabatic winds at both levels are found near the coast and are associated with the steepest ice slopes. Near-surface katabatic winds of 12 $\mathrm{m} \mathrm{s}^{-}$are found along nearly the entire coastal stretch. The influence of the confluence zones is seen in the local katabatic wind enhancement near the Reeves and David glaciers. Wind maxima at the lowest level in excess of $16 \mathrm{~m}$ $\mathrm{s}^{-1}$ are situated across the lower portion of both glaciers; a small $20 \mathrm{~m} \mathrm{~s}^{-1}$ katabatic wind maximum can be seen near Reeves Glacier. Al the second level, the $16 \mathrm{~m} \mathrm{~s}^{-1}$ and $20 \mathrm{~m}$ 


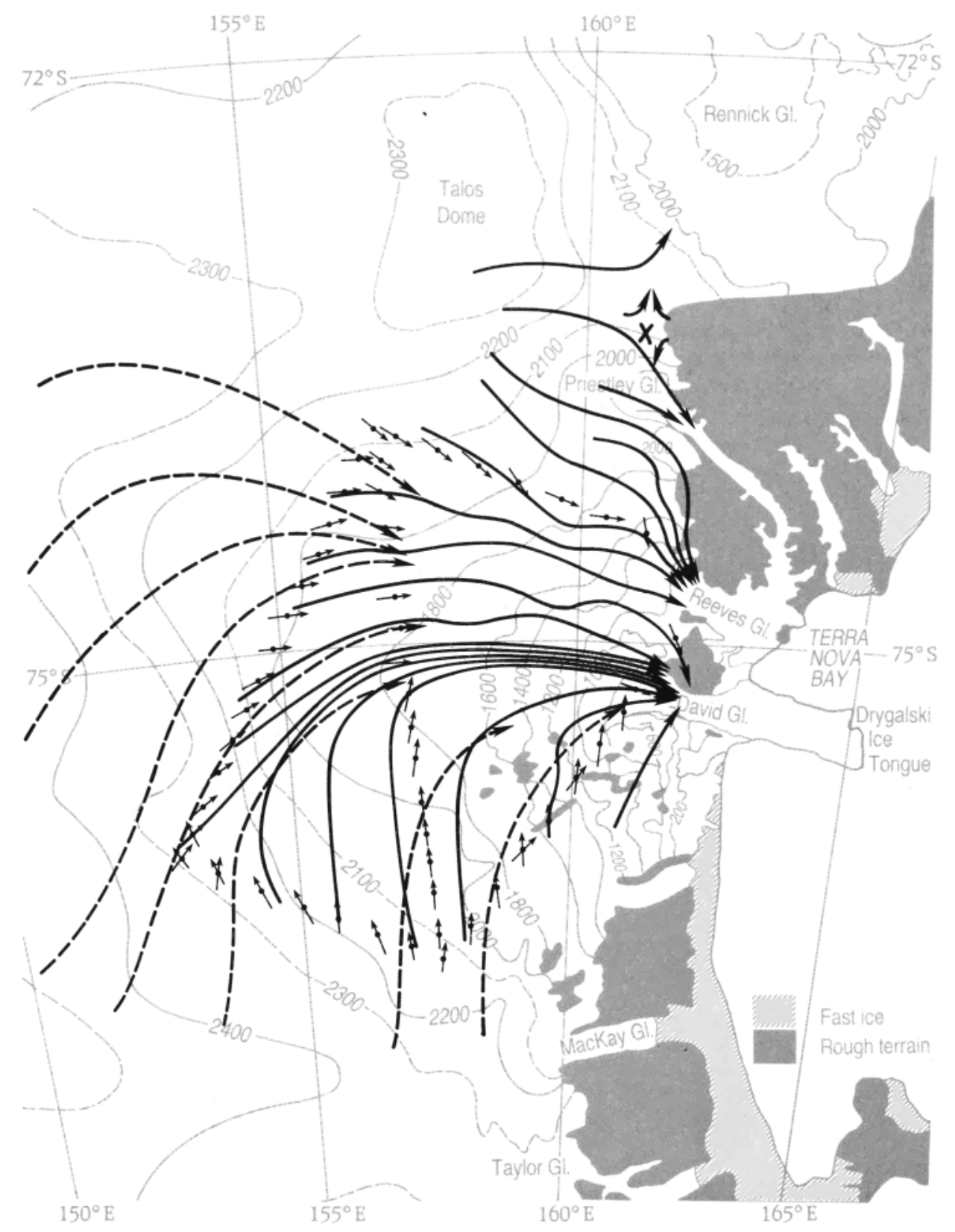

Fig. 7. Comparison between inferred streamlines of surface air motion (heavy solid lines) and those modeled by Parish and Bromwich [1987] (heavy dashed lines). Primary sastrugi directions are plotted at the centerpoint of every tenth 1987 photograph.

$\mathrm{s}^{-1}$ areas have expanded to cover the entire Reeves/David Glacier region. The strongest katabatic winds are therefore associated with the terminal slopes downstream from the confluence zones. Although the broad-scale confluence feature is in agreement with observations and maximum simulated wind speeds occur near the Reeves and David glaciers, there is reason to suspect the core of high katabatic wind speeds in the model is smoothed. Recent instrumented aircraft flights during the Antarctic springtime months indicate the katabatic winds in the vicinity of Terra Nova Bay are frequently in excess of $25 \mathrm{~m} \mathrm{~s}$ and often are localized [Parish and Bromwich, 1989]. Such local katabatic wind maxima are not resolved in this simulation owing to the $32-\mathrm{km}$ grid spacing used in the simulation. Reeves Glacier is only $20 \mathrm{~km}$ wide and stretches for approximately $50 \mathrm{~km}$. The 32-km grid spacing allows only a couple grid points within the confines of the glacier valley and smooths out the terrain significantly. This truncation of the ice terrain almost certainly results in a reduction of the simulated katabatic wind speeds. In addition, the actual topography consists of very rugged and mountainous terrain to the north of Reeves Glacier which acts to further concentrate the airflow into the narrow glacier valley. This barrier effect has been well documented from the sastrugi analysis and may direct a significant airstream down Reeves Glacier. The terrain-induced channeling of the flow may be responsible for an enhanced acceleration of the flow down the steep slopes which is not simulated in this scale of model.

The model simulation is thought to provide a consistent broadscale picture of the katabatic wind drainage over the interior of the continent. The confluence features upslope 


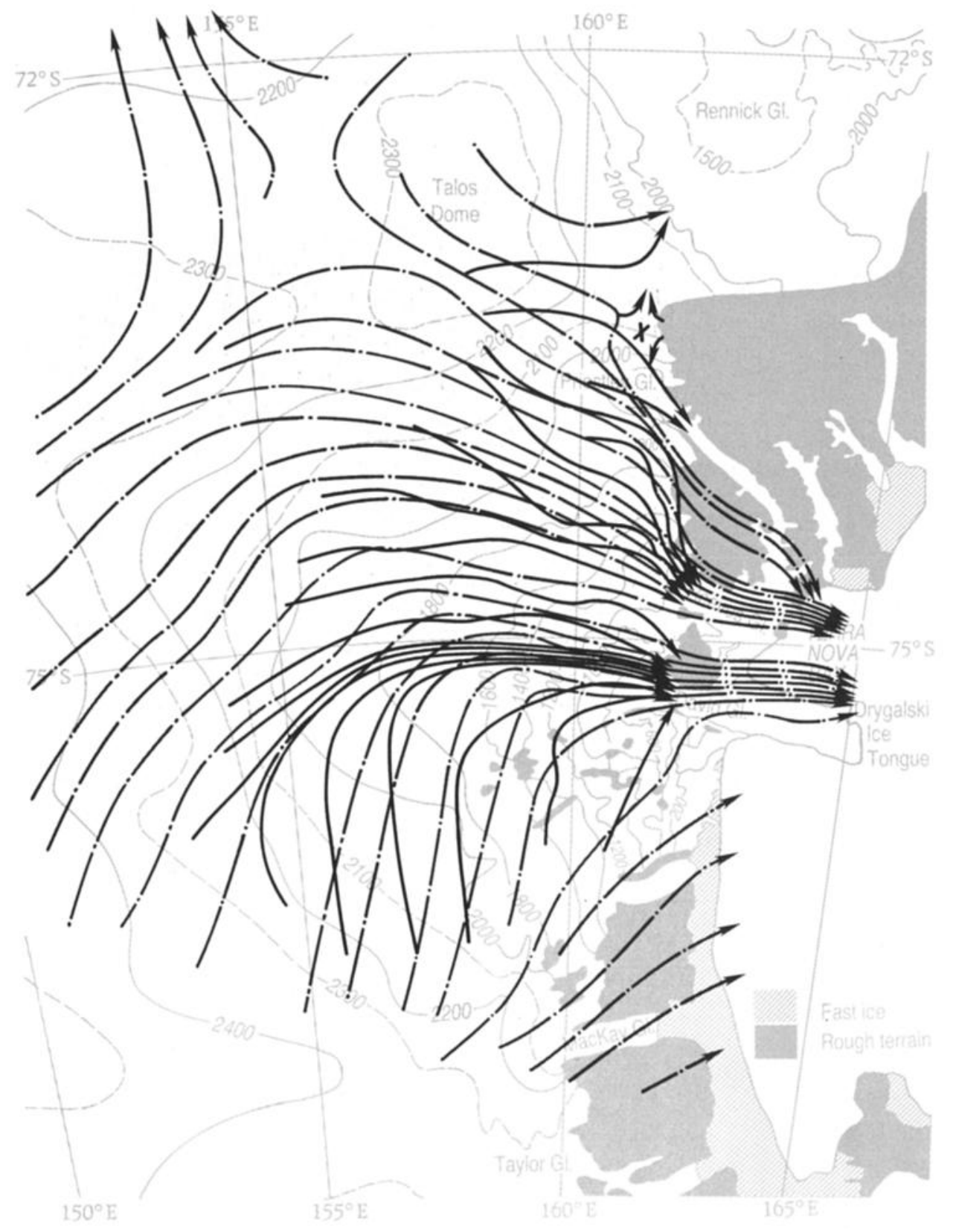

Fig. 8. Inferred streamlines (heavy continuous lines) compared with surface-wind streamlines $(\sigma=1)$ produced by the primitive equation model (heavy dot-dash).

of the Reeves and David glaciers are well resolved and local enhancement of the katabatic regime downslope from the confluence zones is portrayed. Simulated katabatic wind speeds are in reasonable agreement with available observations although localized pockets of strong drainage flow down individual glaciers are not resolved. Model results appear to confirm earlier inferences [Bromwich and Kurtz, 1984] about the importance of the confluence zone and attendant katabatic wind regime on the meteorology of the Terra Nova Bay region.

\section{DISCUSSION AND CONCLUSIONS}

The observed and simulated descriptions of the winter surface wind field over the marginal slopes to the west of Terra Nova Bay were obtained with completely independent approaches. However, when the known limitations of each method are considered, the results are in close agreement. Figure 7 contrasts the streamlines derived from the aircraft sastrugi surveys with the broadscale streamlines modeled by Parish and Bromwich [1987]. The latter generally were terminated near the $1800 \mathrm{~m}$ contour because advective accelerations (e.g., $u \partial u / \partial x$ ) over the steep coastal ice slopes cause the model assumptions to break down. Both the inferred and modeled airflow patterns show the shift from southerly winds in the southern part of the domain around to northwesterly winds upslope from Reeves Glacier. This means that both analyses show a pronounced broadscale streamline confluence just inland from Terra Nova Bay. If allowance is made for the nearly order of magnitude difference in spatial resolution between the observational and modeling results $(5-10 \mathrm{~km}$ versus $50 \mathrm{~km}$ ), it can readily be seen that the results agree to within the limits of error. 
Figure 8 intercompares the sastrugi-derived streamlines in the confluence zone with those simulated by the primitive equation model discussed in section 3. Above the 1800-m contour there is a good overall fit. However, in the southern part of the domain the simulated streamlines are oriented some $20^{\circ}$ more downslope than the inferred ones. This discrepancy is detectable over distances of up to 100 $\mathbf{k m}$, and causes the model to locate the marked confluence zone within the David Glacier valley rather than well into the interior. This difference may be due to a significant directional shear between the winds adjacent to the snow surface and those at an altitude of $20 \mathrm{~m}$ (i.e., at the $\sigma=1$ level). Comparison of Figures $5 a$ and $5 b$ shows that the directional shear from the $\sigma=1$ to the $\sigma=2$ model levels causes the simulated confluence zone feeding into David
Glacier valley to become less well-defined and to move farther downslope.

As the complicated coastal region is approached the fit between the inferred and simulated streamlines is less satisfactory as a result of the $32-\mathrm{km}$ model grid spacing. However it is abundantly clear that the model is reproducing the overall behavior of the airflow. In close agreement with the sastrugi analysis. almost the entire plateau area upslope from Terra Nova Bay is simulated to discharge down the Reeves and David glaciers. Furthermore. the sastrugiderived and modeled streamlines which feed into the central part of Reeves Glacier valley almost overlap; this region has the simplest topography.

The influence of near-coastal topographic smoothing is shown by the model's inability to locate the northern and

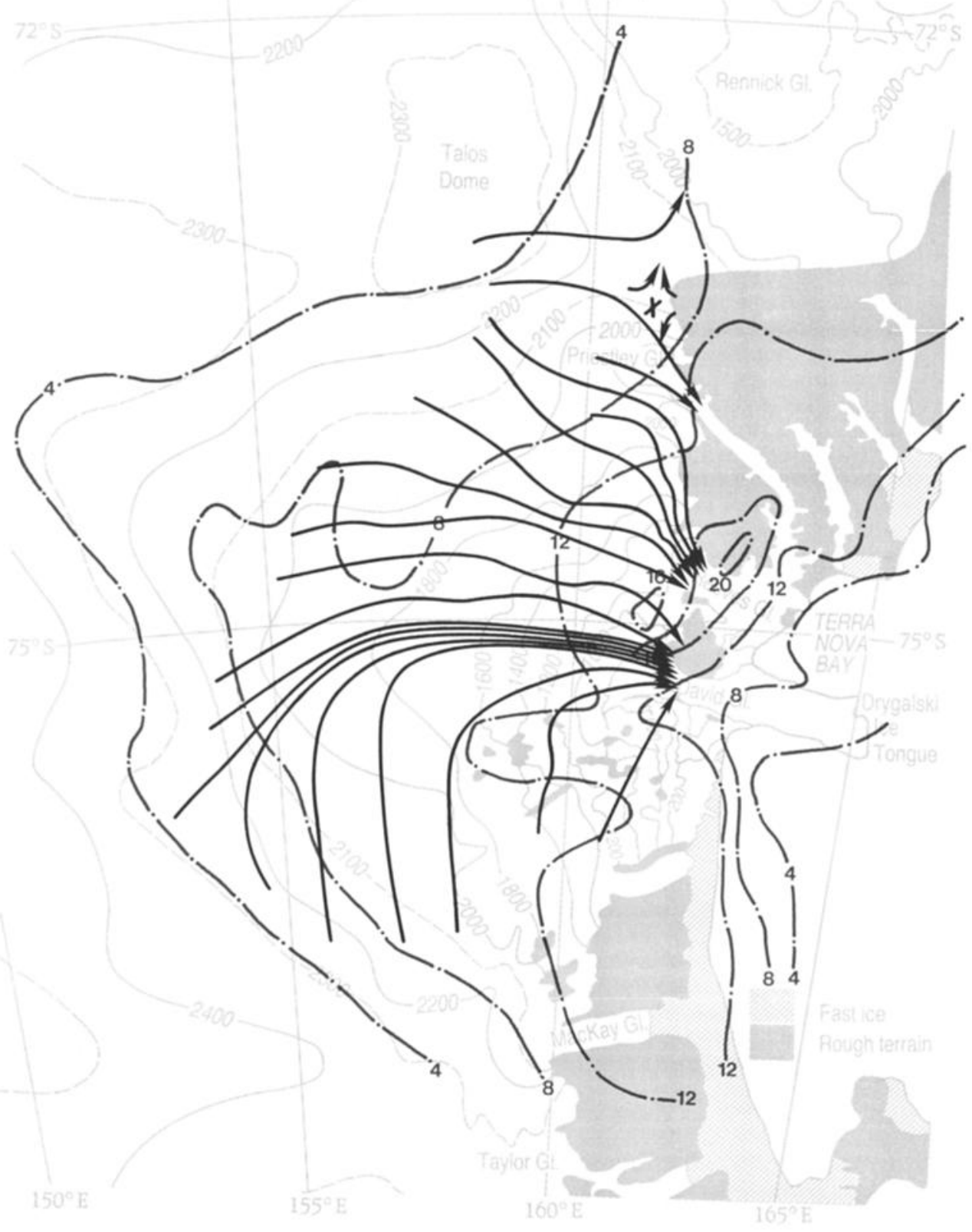

Fig. 9. Inferred streamlines (heavy continuous lines) compared with primitive equation surface-wind speeds in $\mathbf{m ~ s}^{-1}$ (heavy dot-dash). 
southern confluence zones completely within the confines of Reeves and David glaciers. Neither does the model simulate a marked barrier jet blowing into Reeves Glacier valley. Simulated airflow is not directed into the head of Priestley Glacier, but a reflection of this drainage does seem to be produced farther downslope. It is highly likely that these coastal drainage details would be reproduced by model simulations using a much smaller grid spacing than $32 \mathrm{~km}$.

Comparisons between the inferred streamlines and modeled isotachs (Figure 9) also provide important results. The strongest katabatic winds are found just to the north of Reeves Glacier; this result is much more pronounced for the $\sigma=2$ level. It arises because the Coriolis force concentrates katabatic airflow on the left side (looking downwind) of a broadscale topographic trough [Ball, 1960]. As a result, the katabatic mass transport down Reeves Glacier should substantially exceed that emerging from David Glacier valley.

Examination of Figure $6 b$ reveals that the model produces the strongest winds $\left(>20 \mathrm{~m} \mathrm{~s}^{-1}\right.$ ) around $600-\mathrm{m}$ elevation. This near-coastal convergence is primarily generated by the smoothed topograpy just to the north of Reeves Glacier/Terra Nova Bay (Figure 1). The sastrugi-derived streamlines denonstrate that this convergence actually takes place above the $1200-\mathrm{m}$ contour, and is generated by the steep mountains to the southwest of Priestley Glacier. The smoothed model topography, which does not resolve these coastal details, produces a broader and more seaward katabatic jet than inferred.

The main conclusions of this study can be summarized as follows.

1. The overall picture of the intense katabatic airstream at Terra Nova Bay being forced by converging air currents in the continental interior is well supported by both observations and numerical modeling.

2. Most discrepancies between model results and observations are readily explained by the spatial resolution used in the model calculations. Finer scale grids are needed to reproduce the near-coastal drainage features shown by the sastrugi surveys.

3. Airborne photographic surveys of the ice sheet surface provide a demonstrated, high quality method for detailed spatial mapping of the time-averaged surface motion field. However, the spatial resolution of some satellite sensors (e.g., 10-20 $\mathrm{m}$ of SPOT (Système Probatoire d'Observation de la Terre)) is at or approaching that required for sastrugi surveys (compare Figure 2), and satellite remole sensing may provide an alternative source of data. The results presented here as well as by Parish and Bromwich [1987] demonstrate that for many areas the interior Antarclic surface wind field is characterized by strong spatial variability. Both cross-slope and downslope variations of the surface wind must be considered when future field progranis are designed.

4. The primary route in this area for katabatic mass transport to sea level is Reeves Glacier valley. The mountain deflection north of the valley head plays an essential role in setting up this near-coastal convergence. An important secondary katabatic airflow emerges from David Glacier; this is sustained by a confluence zone which stretches at least $100 \mathrm{~km}$ into the interior.

Acknowledgments. We are grateful to Jerry Mullins of the USGS for planning and coordinating the sastrugi survey flights and to the U.S. Navy for flying the missions. Kathleen Doddroe typed the manuscript, and Yvonne Holsinger drafted the figures. We thank all these individuals for their high quality and essential support. This research was funded by National Science Foundation grants DPP-8519977 (D.H.B.) and DPP-8521176 (T.R.P.). Byrd Polar Research Center, Ohio State University, contribution 670 .

\section{REFERENCES}

Alley, R.B., Concerning the deposition and diagenesis of strata in polar firn, J. Glaciol. . 34. 283-290. 1989.

Anthes. R.A., and T.T. Warner. Development of hydrodynamical models suitable for air pollution and other mesometeorological studies, Mon. Weather Rev.. I06, 1045-1078. 1978.

Ball. F.K., The theory of strong katabatic winds, Aust. J. Phys., 9, 373-386, 1956.

Ball, F.K., Winds on the ice slopes of Antarctica, Anfarctic Meteorology. Proceedings of the Symposium, Melbourne, 1959, pp. 9-16, Pergamon. New York, 1960.

Blackadar. A.K., High-resolution models of the planetary boundary layer, Advances in Environmental and Scientific Engincering, vol. I, pp. 51-85, Gordon and Breach. New York. 1978.

Bromwich. D.H., Snowfall in high southern latitudes, Rev. Geophys.. 26(1). 149-168, 1988.

Bromwich. D.H., An extraordinary katabatic wind regime at Terra Nova Bay, Antarctica, Mon. Weather Rev., 117, 688-695, 1989.

Bromwich, D.H. , and D.D. Kurt. Experiences of Scott's Northern Party: Evidence for a relationship between winter katabatic winds and the Terra Nova Bay polynya, Polar Rec., 21. 137-146, 1982.

Bromwich. D.H., and D.D. Kurtz, Katabatic wind forcing of the Terra Nova Bay polynya, J. Geophys. Res., 89. 3561-3572, 1984.

Bromwich, D.H., T.R. Parish, and C.A. Zorman, Observational and modeling studies of the Terra Nova Bay confluence zone, in Second Conference on Polar Meleorology and Oceanography. pp. 101-104, American Meteorological Society, Boston, Mass.. 1988.

Bryazgin, N.N., Method of preparing monthly charts of atmospheric precipitation in Antarctica, in Climate of Antarctica, edited by 1.M. Dolgin, pp. 109-1 16. Oxonian, New Delhi. 1986.

Cerni, T.A., and T.R. Parish, A radiative model of the stable nocturnal boundary layer with application to the Polar night, $J$. Clim. Appl. Meicorol.. 23, 1563-1572, 1984

Doumani, G.A. Surface structures in snow, in Physics of Snow and lce. Proceedings of Imermational Conference on Snow and Ice, Sapporo, 1966, vol. 1. part 2, edited by H. Oura, pp. 1119-1136, Institute of Low Temperature Science, Hokkaido University, Japan, 1967.

Drewry, D.J.. The surface of the Antarctic ice sheet. in Antarctica: Glaciological and Geophysical Folio, sheet 2. edited by D.J. Drewry, Scott Polar Research Institute. University of Cambridge. England, 1983.

Fujiwara. K., and Y. Endo, Preliminary report of glaciological studies, in Report of the Japanese Traverse Syowa-Soulh Pole 1968-1969,pp.68-109,edited byM. Murayama, PolarResearchCenter, National Science Museum, Tokyo. 1971.

James, I.N., On the forcing of planetary-scale Rossby waves by Antarctica, Q.J.R. Meteorol. Soc., /14, 619-637, 1988.

Kurtz, D.D., and D.H. Bromwich. Satellite observed behavior of the Terra Nova Bay polynya, J. Geophys. Res., 88, 9717-9722, 1983.

Kurt, D.D., and D.H. Bromwich, A recurring, atmospherically forced polynya in Terra Nova Bay, in Oceanology of the Antarctic Continental Shelf, Antarct. Res. Ser., vol. 43. pp. 177-201, edited by S.S. Jacobs, AGU, Washington, D.C.. 1985.

Mather, K.B., Further observations on sastrugi, snow dunes and the pattern of surface winds in Antarctica, Polar Rec., $11,158-171$, 1962.

Mather, K.B., and G.S. Miller, Notes on topographic factors affecting the surface wind in Antarctica, with special reference to katabatic winds, and bibliography, Rep. UAG R-189, 125 pp., Geophys. Inst., Univ. of Alaska. Fairbanks. 1967

Okuhira. F., and H. Narita. A study of formation of a surface snow layer. in Glaciological Siudies in Mizuho Plateau, East Antarctica, 1969-1975, pp. 140-153, edited by T. Ishida, National Institute of Polar Research. Tokyo. 1978.

Parish, T.R., The katabatic winds of Cape Denison and Port Martin. Polar Rec., 20. 525-532, 1981.

Parish, T.R., Surface airflow over East Antarctica, Mon. Weather Rev., 110, 84-90, 1982.

Parish. T.R., A numerical study of strong katabatic winds over Antarctica, Mon. Wealher Rev., /12, 545-554, 1984

Parish, T.R., and D.H. Bromwich, The surface windfield over the Antarctic ice sheets, Nalure, 328, $51-54,1987$.

Parish, T.R., and D.H. Bromwich, Instrumented aircraft observations of the katabatic wind regime near Terra Nova Bay, Mon. Wealher Rev., II7, 1570-1585, 1989.

Parish, T.R.. and K.T. Waight, The forcing of Antarctic katabatic winds, Mon. Weather Rev., IIS, 2214-2226, 1987.

Phillpot, H.R., and J.W. Zillman, The surface temperature inversion over the Antarctic continent, J. Geophys. Res., 75, 4161-4169, 1970.

Polar Research Board, The Polar Regions and Climatic Change, Appendix, 113 pp.. National Academy Press, Washington, D.C.. 1984.

Roscoe, J.H., Antarctica, Air Force Manual AFM 200-30, 171 pp.. Intelligence, Regional Photo Interpretation Ser., Dep. of the Air Force, Washington, D. C., 1953. 
Schwerdtfeger, W.. Weather and Climate of the Antarctic. 261 pp.. Elsevier, New York, 1984.

Stearns, C.R., and G. Wendler, Research results from Antarctic automatic weather stations, Rev. Geophys., 26(1), 45-61, 1988.

Walanabe, O., Distribution of surface fearures of snow cover in Mizuho Plateau. in Glaciological Studies in Mizuho Plateau, East Antarctica, 1969-1975, pp. 44-62, edited by T. Ishida, National Institute of Polar Research. Tokyo, 1978.

Wendler, G., Measuring blowing snow in Adelie Land. Eastern Antarctica, in Second Conference on Polar Meleorology and Oceanography, pp. 93-96, American Meteorological Society, Boston, Mass., 1988.
D.H. Bromwich, Byrd Polar Research Center, Ohio State University, Columbus, $\mathrm{OH} 43210$.

T.R. Parish, Department of Atmospheric Science, University of Wyoming, Laramie, WY 82071.

C.A. Zorman, Department of Physics, Case Western Reserve University. Cleveland, OH 44106.

(Received September 26, 1988

revised Sepiember 14, 1989;

accepted September 14, 1989.) 